\title{
腎孟・尿管癌に合併した膀胱癌の異型度と深達度に関する検討
}

\author{
1)立川共済病院泌尿器科 \\ 2)長久保クリニック \\ 塚本 拓司 ${ }^{1)}$ 藤岡 俊夫 ${ }^{1)}$ 山内 智之 ${ }^{1)}$ \\ 森義明 ${ }^{11}$ 長久保一朗 ${ }^{21}$
}

\section{RELATIONSHIP BETWEEN GRADE AND STAGE OF RENAL PELVIC AND/OR URETERAL TUMOR AND ASSOCIATED BLADDER TUMOR}

Takuji Tsukamoto1), Toshio Fujioka ${ }^{1)}$, Tomoyuki Yamauchi ${ }^{1}$, Yoshiaki Mori $^{1)}$ and Ichiro Nagakubo ${ }^{2)}$

The Department of Urology, Tachikawa Kyousai Hospital ${ }^{1)}$, and Nagakubo Clinic ${ }^{2)}$

(Objective) The purpose of this study was to analyze bladder tumor (BT) associated with renal pelvic and/or ureteral tumor (RUT), with emphasis on the relationship between the grade and stage of these tumors.

(Methods) We reviewed 77 cases of RUT operated upon at our hospital during the last 14 years. We herein define stage $\mathrm{T} 1 \mathrm{~b}$ tumor as invasive since this stage of tumor is considered to have a different biologic behavior and potential compared to stage Ta tumor.

(Results) Of the 77 patients, 29 had associated BTs: 8 with a concomitant BT, 3 with BT antedating RUT, and 18 with a subsequent BT. In addition, one patient with preceding BT and two with concomitant cases developed BT after the RUT operation, permitting 21 cases to be categorized in the subsequent BT group.

Thirty one out of 32 cases of associated BTs had the same or a lower grade of RUT while one patient who initially had G2 T1b RUT developed G3 T2 BT 5 years after total nephroureterectomy.

In the preceding cases, two patients with Ta BTs had Ta RUTs, and one patient with T1b BT antedated T2 RUT. In the concomitant BTs, all four cases with stage Ta RUT exhibited Ta BT, and another four with invasive RUT presented invasive BT. In the subsequent cases, 18 out of 21 patients developed Ta BT.

(Conclusion) In the preceding and concomitant cases, associated BT \& RUT tend to have the same nature, that is, to be either invasive or non-invasive. In contrast to these cases, 18 out of 21 patients in subsequent cases developed Ta BT. However, since three out of 10 patients with invasive RUT subsequently developed invasive BTs, careful follow-up for invasive RUT should be mandatory to detect recurrent invasive BTs in their early stage.

Key words: renal pelvic and/or ureteral tumor, associated bladder tumor

要旨：(目的)腎孟・尿管癌とこれに合併した膀胱癌について, 両者の異型度と深達度の関係を検討した.

（方法）当院にて腎尿管全摘除術を施行した腎孟・尿管癌77例を対象とした. 合併膀胱癌はその発生 時期から，腎孟・尿管癌に先行した例（先行例），同時に認められた例（同時例），術後に生じた例（続 発例）に分類した。なお，今回の検討においては浸潤癌を深達度 $\mathrm{T} 1 \mathrm{~b}$ 以上の腫瘍とした。

(結果) 膀胱癌は 29 例に合併し, この内先行例 3 例, 同時例を 8 例認めた. 続発例は 18 例であったが, 先行例 1 例と同時例 2 例に膀胱癌が続発し，これら 3 例を加えた 21 例を続発例とした。

合併膀胱癌の異型度は，1例を除き，腎盂・尿管癌と同じか低下していた。 
深達度に関しては，先行例と同時例で $\mathrm{Ta}$ 腎孟・尿管癌には全例 $\mathrm{Ta}$ 膀胱癌が，浸潤性（T1b 以上） 腎孟・尿管癌には浸潤性膀胱癌が合併した。また，Ta 腎孟・尿管癌に続発した 11 例の膀胱癌は全例 $\mathrm{Ta}$ であった。一方, 浸潤性腎孟・尿管癌に続発した 10 例の膀胱癌のうち 7 例は Ta で, 浸潤性膀胱癌の合併 は 3 例であった。

（結論）先行例と同時例では，腎孟・尿管癌と膀胱癌の浸潤性は等しくなる傾向が認められた．続発 例においては Ta 膀胱癌が多く合併したものの, 浸潤性腎孟・尿管癌に続発した膀胱癌は 10 例中 3 例が浸 潤性であった。合併数は少ないものの, 浸潤性腎孟・尿管癌の術後では浸潤性膀胱癌の発生に関し, 特 に注意深い経過観察が必要と思われた。

キーワード：腎孟・尿管癌, 合併膀胱癌

\section{緒 言}

腎孟・尿管癌と膀胱癌は合併頻度の高いことが以前 より報告され ${ }^{1)}$ ，尿路上皮癌の発生や再発の機序を考 える上で興味深く ${ }^{2)}$, 様々な検討がなされている。

腎孟・尿管癌に合併した膀胱癌はその発生時期から, 膀胱癌が腎盂・尿管癌に先行するもの (先行例), 同時 に認められるもの (同時例), 腎孟・尿管癌術後に発生

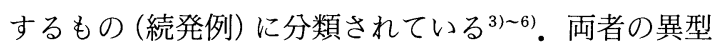
度と深達度の関係に言及した報告は多(が3( -6)10111), 詳細に比較検討した報告はわれわれの知り得る限りで は認められない。そこで, 当院で経験した腎孟・尿管 癌と膀胱癌の合併例を対象に両者の関係を検討した。 その結果, 腎孟・尿管癌と膀胱癌に関する幾つかの知 見を得たので，これを報告する。

\section{対象・方法}

1982年から1995年の14年間で，当院にて腎尿管全摘 術を施行した腎孟・尿管癌77例を対象とした。

腎孟・㽷管癌に合併した膀胱癌は, 前述の如く, そ の発生時期によって先行例 - 同時例 - 続発例に分類し た。なお，今回の検討において，同時例は腎孟・尿管 癌と膀胼癌に病理学的連続性のない症例とした。すな わち, 同時に両者が認められても, 腫湟の連続性があ る場合は腎盂・尿管癌の膀胱浸潤と考え, 合併例から 除外した。また，全例術前に膀胱鏡検査が施行され， 膀胱癌の有無は確認されている. 術後の膀胱癌合併に 関しては, 全例定期的に(術後 5 年間は $3 \sim 4$ 力月毎, 以降 6 力月〜 1 年毎) 膀胱鏡検査を行い検索した. 膀 胱内注入療法は膀胱癌の合併がない限り行わなかっ た.

腎孟・尿管癌及び膀胱癌の記載は，それぞれの取り 扱い規約に準じた。なお, 複数の異型度が混在した症 例では最も高いものを代表とした。一方，一つの腫場 内に幾つかの発育様式が混在する場合はこれを列記 し, 記号>によりある発育様式を示す範囲が他に比し
て優位であることを示した。また，尿管癌の位置は， 摘出尿管の全長を 3 等分し, 腫瘍の点拠部位から上中 下に分類した。

\section{結 果}

対象症例は男性51例・女性26例から構成されていた。 その年齢は 32 歳から 83 歳, 平均65歳であった。腎盂・ 尿管癌全例の異型度・深達度は表 1 に示した。 なお, 手術が行われたものの, 摘出標本の病理が確認できな かった症例を 1 例を認めた。

腎孟・㽷管癌の発生部位は, 腎孟にのみ認められた 症例が37例, 腎孟 + 上部尿管 2 例, 腎孟 + 中部尿管 2 例, 腎孟 + 下部尿管 2 例, 腎孟十尿管全長に渡って認 められた 2 例, 中部尿管 12 例, 中部 + 下部尿管 4 例, 下部尿管16例であった。

膀胱癌は77例中 29 例に合併した。この内, 同時例は 8 例, 先行例 3 例, 続発例 18 例であった. 同時例 2 例 と先行例 1 例には腎尿管全摘出術後に膀胱癌が続発 し,これら 3 例を加えた 21 例を続発例とした.表 $2 \sim 5$ に32例の各症例について, 腎孟・尿管癌と合併膀胱癌 の異型度・深達度及び腫瘍発育様式を示した。更に, 同時例と続発例における異型度と深達度の関係を表 6 にまとめた。

なお, 今回の検討では深達度 T1b 以上の腫瘍を浸潤

表 1 腎孟・尿管癌77例の深達度と異型度

\begin{tabular}{c|r|r|r|r|r|r|r}
\hline 深達度 & TIS & Ta & T1b & T2 & T3 & T4 & 合計 \\
\hline G1 & 0 & 8 & 0 & 0 & 0 & 0 & 8 \\
\hline G2 & 1 & 15 & 4 & 4 & 12 & 2 & 38 \\
\hline G3 & 0 & 3 & 7 & 7 & 11 & 1 & 29 \\
\hline 腺癌 & 0 & 0 & 0 & 0 & 0 & 1 & 1 \\
\hline 合計 & 1 & 26 & 11 & 11 & 23 & 4 & 76 \\
\hline
\end{tabular}

*摘出標本の病理不明 1 例 
表 2 先行症例

\begin{tabular}{|c|c|c|c|c|c|c|c|}
\hline & 胱 & 癌 & & 腎 & · 尿 & 管 & \\
\hline 異型度 & 媣達度 & 発育様式 & 発生時期 & 位置 & 異型度 & 深達度 & 発育様式 \\
\hline G1 & $\mathrm{Ta}$ & PNT & 41力月後 & 尿管下 & G1 & $\mathrm{Ta}$ & PNT \\
\hline G2 & $\mathrm{Ta}$ & PNT & 36力月後 & 腎孟 & G2 & $\mathrm{Ta}$ & PNT \\
\hline G3 & T1b & ${ }^{*}$ PNT \& NIT & 60 力月後 & 尿管中+下 & G3 & $\mathrm{T} 2$ & NIT \\
\hline
\end{tabular}

*乳頭状非浸潤癌と非乳頭状浸潤癌の混在を表す。

表 3 同時症例

腎孟・尿管癌が浸潤癌 (T1b 以上)

\begin{tabular}{|c|c|c|c|c|c|c|}
\hline & 需 & - 尿 & 癌 & & 胱 & 癌 \\
\hline 位 置 & 異型度 & 深達度 & 発育様式 & 異型度 & 深達度 & 発育様式 \\
\hline 尿管下 & G2 & $\mathrm{T} 3$ & PIT & G2 & $\mathrm{T} 1 \mathrm{~b}$ & PIT \\
\hline 腎盂 & G3 & T3 & PIT & G2 & $\mathrm{T} 1 \mathrm{~b}$ & PIT \\
\hline 腎孟＋尿管中 & G2 & $\mathrm{T} 3$ & NIT & G2 & T3a & NIT \\
\hline 腎孟十尿管下 & G3 & T3 & NIT $>$ PIT & G3 & $\mathrm{T} 2$ & PIT \\
\hline
\end{tabular}

腎孟・尿管癌が非浸潤癌 $(\mathrm{Ta})$

\begin{tabular}{c|c|c|c|c|c|c}
\hline \multicolumn{2}{r|}{ 腎 孟 ・ 尿 管 癌 } & \multicolumn{3}{|c}{ 膀 胱 癌 } \\
\hline 位 置 & 異型度 & 深達度 & 発育様式 & 異型度 & 深達度 & 発育様式 \\
\hline 腎孟 & $\mathrm{G} 1$ & $\mathrm{Ta}$ & $\mathrm{PNT}$ & $\mathrm{G} 1$ & $\mathrm{Ta}$ & $\mathrm{PNT}$ \\
\hline 腎孟 & $\mathrm{G} 1$ & $\mathrm{Ta}$ & $\mathrm{PNT}$ & $\mathrm{G} 1$ & $\mathrm{Ta}$ & $\mathrm{PNT}$ \\
\hline 腎孟 & $\mathrm{G} 2$ & $\mathrm{Ta}$ & $\mathrm{PNT}$ & $\mathrm{G} 1$ & $\mathrm{Ta}$ & $\mathrm{PNT}$ \\
\hline 尿管中 & $\mathrm{G} 2$ & $\mathrm{Ta}$ & $\mathrm{PNT}$ & $\mathrm{G} 2$ & $\mathrm{Ta}$ & $\mathrm{PNT}$ \\
\hline
\end{tabular}

\section{表 4 続発症例}

腎孟・尿管癌が非浸潤癌 (Ta)

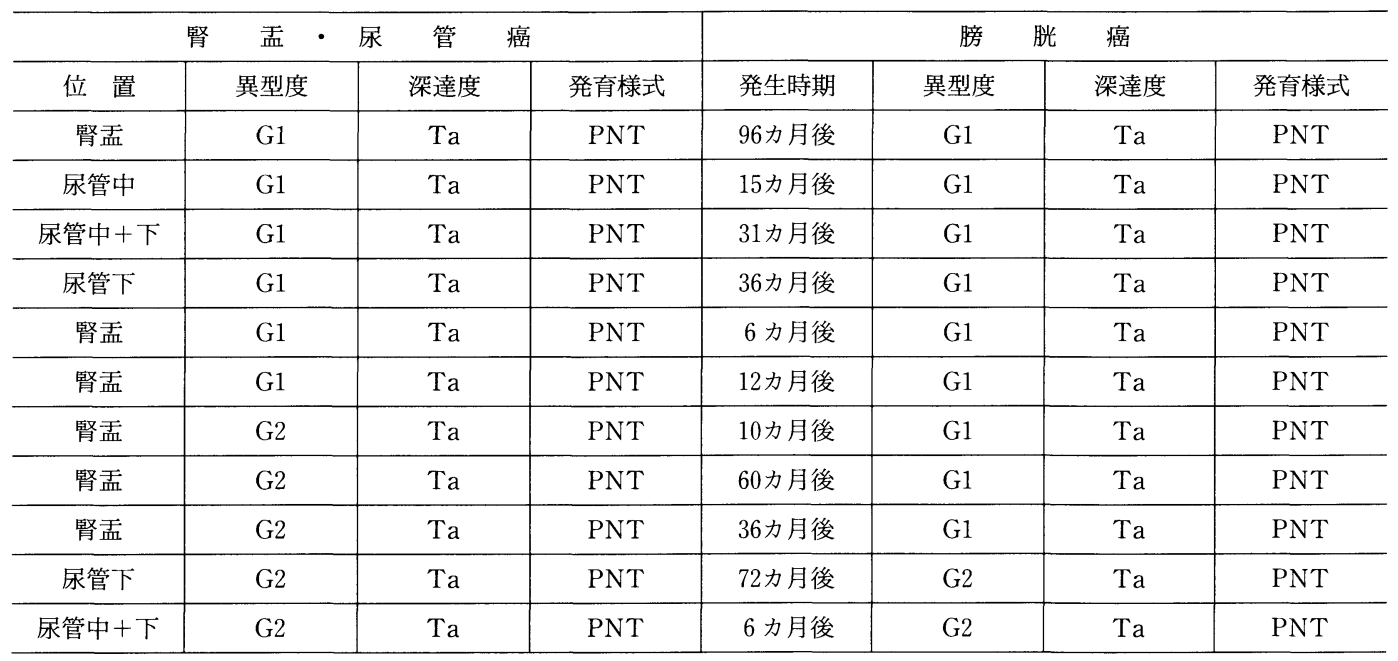


表 5 続発症例

腎孟・尿管癌が浸潤癌 (T1b 以上)

\begin{tabular}{|c|c|c|c|c|c|c|c|c|}
\hline & 孟 & - 尿 & 管 & 癌 & & 膀 & 癌 & \\
\hline 位 置 & 異型度 & & 深達度 & 発育様式 & 発生時期 & 異型度 & 深達度 & 発育様式 \\
\hline 腎盂十尿管中 & G2 & & $\mathrm{T} 1 \mathrm{~b}$ & PIT & 29力月後 & G2 & $\mathrm{Ta}$ & PNT \\
\hline 尿管中+下 & G3 & & $\mathrm{T} 1 \mathrm{~b}$ & NIT $>$ PIT & 12 力月後 & G2 & $\mathrm{Ta}$ & PNT \\
\hline 腎孟 & G3 & & $\mathrm{T} 2$ & NIT $>$ PIT & 180 力月後 & $\mathrm{G} 2$ & $\mathrm{Ta}$ & PNT \\
\hline 腎孟 & $\mathrm{G} 2$ & & T3 & PIT & 6 力月後 & G2 & $\mathrm{Ta}$ & PNT \\
\hline 腎盂 & $\mathrm{G} 2$ & & T3 & PIT & 5力月後 & G1 & $\mathrm{Ta}$ & PNT \\
\hline 腎孟 & $\mathrm{G} 2$ & & $\mathrm{~T} 3$ & PIT & 108力月後 & $\mathrm{G} 2$ & $\mathrm{Ta}$ & PNT \\
\hline 腎盂 & G2 & & T3 & PIT & 5力月後 & G2 & $\mathrm{Ta}$ & PNT \\
\hline 尿管下 & G2 & & $\mathrm{T} 1 \mathrm{~b}$ & PIT & 60 力月後 & G3 & $\mathrm{T} 2$ & PIT \\
\hline 尿管中 & G3 & & $\mathrm{T} 2$ & NIT & 6力月後 & G2 & $\mathrm{T} 1 \mathrm{~b}$ & NIT \\
\hline 尿管中 & $\mathrm{G} 2$ & & $\mathrm{~T} 2$ & NIT $>$ PIT & 204力月後 & G2 & $\mathrm{T} 1 \mathrm{~b}$ & PIT \\
\hline
\end{tabular}

上段は続発性膀胱癌が $\mathrm{Ta}$ の症例

下段は続発性膀胱癌も浸潤癌症例

表 6 同時例と続発例の異型度と深達度

同時例の異型度

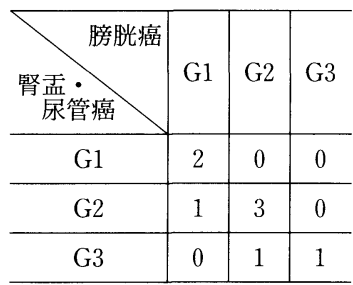

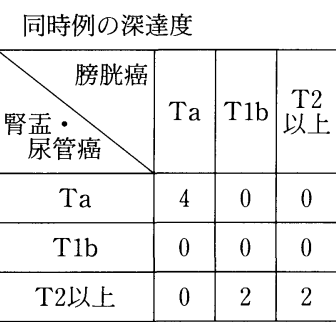

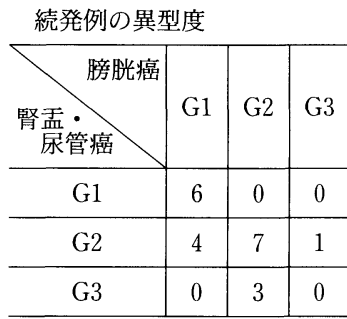

\begin{tabular}{|c|c|c|c|}
\hline $\begin{array}{l}\text { 膀胱癌 } \\
\text { 腎需. } \\
\text { 原管癌 }\end{array}$ & $\mathrm{Ta}$ & T1b & $\begin{array}{l}\mathrm{T} 2 \\
\text { 以上 }\end{array}$ \\
\hline $\mathrm{Ta}$ & 11 & 0 & 0 \\
\hline $\mathrm{T} 1 \mathrm{~b}$ & 2 & 0 & 1 \\
\hline $\mathrm{T} 2$ 以上 & 5 & 2 & 0 \\
\hline
\end{tabular}

癌とした.これに関しては異論があるとは思われるが, $\mathrm{T} 1 \mathrm{~b}$ 膀胱癌ではりンパ節転移や遠隔転移を生じる症 例を認め ${ }^{7) ~ 9)}, \mathrm{Ta}$ の膀胱癌とは明らかにその予後が異 なることから ${ }^{7)}$, 浸潤癌に分類した。

まず，異型度につき検討すると，先行例においては 両者の異型度は 3 例とも一致していた（表 2 )。次に, 同時例では腎孟・尿管癌と膀胱癌の異型度は G3 と G2 のそれぞれ 1 例を除き 1 致していた（表 $3 ， 6$ )。続発 例では腎孟・尿管癌が G1の 6 例全例に G10膀胱癌が 発生した（表 4,6 ).
一方，G3の 3 例は膀胱癌において全例 $\mathrm{G} 2$ と異型度の 低下が認められた (表 $5 ， 6$ )。G2の腎孟・尿管癌は 12 例で，このうち11例では膀胱癌の異型度は同じか低下 していた（表 4，5，6）。異型度の進行を認めた G2 の 1 例は, 合併例 32 例の内膀胱癌の異型度が腎孟・尿 管癌に比べ高い唯一の症例で, G2T1b の尿管癌の術後 5 年目に G3T2の膀胱癌が発生した症例であった（表 5 ).

次に, 深達度に関して検討を行った。 まず, 先行例 において Ta の症例では両者の深達度は等しかった。 膀胱癌が $\mathrm{T} 1 \mathrm{~b}$ の症例では $\mathrm{T} 2$ の尿管癌が 5 年後に発生 した (表 2 ). 次に, 同時例の 8 例では, 腎孟・尿管癌 が Ta の 4 例は膀胱癌も全例 Ta であった. 他の 4 例 の腎盂・尿管癌は全て T3の浸潤癌で，同時に認められ た膀胱癌は T1b 2 例, T2 1 例, T3a が 1 例であった (表 3,6 ). 前述の如く, T1b の腫瘍を浸潤癌と考元 ると, 先行例及び同時例では腎孟・尿管癌が非浸潤癌 の場合は膀胱癌も非浸潤癌が, そして浸潤癌では膀胱 癌も浸潤癌が合併し, 両者に浸潤性の点で一致をみた。 最後に, 続発例21例の腎孟・尿管癌を非浸潤癌と浸潤 癌に分けて, それぞれの続発性膀胱癌の深達度を検討 した。まず, 11例の Ta 腎孟・尿管癌においては, 全て の続発性膀胱癌の深達度は Ta であった.すなわち, 全 ての症例で深達度の一致を認めた（表 4,6 ）。一方, 浸潤性腎盂・尿管癌に続発した10例の膀胱癌の内 7 例 は Taであり, 浸潤癌が生じた症例は 3 例のみであっ 
た（表 5,6 ).

\section{考察}

今回の検討において，腎盂・尿管癌と膀胱癌が同時 に認められた症例では, 腎孟・尿管癌が Ta の場合は膀 胼癌も全例が Ta であり, T1b 以上の浸潤癌の際には 膀胱癌も同様に $\mathrm{T} 1 \mathrm{~b}$ 以上であった (表 6 ). また, 症例 数は 3 例と少ないものの，先行例においても同様の傾 向が認められた。今回, 同時例とした症例は, 腎盂・ 尿管癌と膀胱癌の間に病理学的連続性のない症例であ り, 従って, 膀胱癌は腎孟・尿管癌の直接進展により 生じたものではない.

このように，独立した二つの腫瘍が浸潤性の点で, 等しい性格を有することは興味深い. 同時例の深達度 に関する報告は少ないが, Lunec らは浸潤癌が同時に 認められた症例の遺伝子解析から, 両者が単一クロー ンより生じた可能性を報告している ${ }^{10)}$. 更に, 浸潤癌の 症例のみならず，Murphy らは G1Ta の腎孟・尿管癌 に同時に認められた膀胱癌は全例 G1Taであった と ${ }^{3)}$ われわれと同様の報告をしている.また, 先行例 に関しては, Shinka らの報告した12例中10例に両者の 浸潤性の一致が認められる ${ }^{11)}$.すなわち, 同時性もしく は異時性に膀胱癌と腎孟・尿管癌が合併する場合, こ れらの腫瘍は浸潤性か非浸潤性かという点で等しくな る傾向が認められると考えられる。

一方, 膀胱癌が続発した症例においては, 腎孟・尿 管癌が Ta の場合両者の深達度は一致するものの, 浸 潤癌では 10 例中 7 例で Ta 膀胱癌が生じていた。文献 上も続発性膀胱癌に関しては, 腎盂・尿管癌の深達度 と関係なく表在性膀胱癌が多く認められるという報告 が多( ${ }^{4) 5}$. では，続発例の場合は先に同時例や先行例 で認められた傾向，すなわち，腎孟・尿管癌と膀胱癌 の浸潤性の一致をみることはないのであろうか.

腎孟・尿管癌に関しては膀胱癌の続発が多いことか ら，術後定期的に膀胱鏡検査を行うことが必要とされ ている ${ }^{6)}$.この結果, 同時例と異なり, 続発例では膀胱 癌が発生より短期間の内に発見されている可能性があ る.上条らも続発例に表在性膀胱癌が多い理由として, 術後の膀胱鏡検査で腫瘍が早期に治療されている可能 性を指摘している4).

Koss らの膀胱全摘標本に対するマッピングの報告 以来, 非浸潤性乳頭状膀胱癌と浸潤性膀胱癌はその初 期から異なる発生経路をたどると考えられている ${ }^{12}$. ところが, Kakizoe らは膀胱癌の全摘標本を詳細に検 討した結果から，一部の浸潤癌，特に腫瘍発育様式が
PIT の腫瘍は PNT 腫瘍から発生する可能性を指摘し $た^{13)}$.また, Sidransky らも分子生物学的な研究結果よ り，一部の浸潤癌が乳頭状腫瘍から生じる可能性を報 告している ${ }^{14)}$. 自験例において, Ta 膀胱癌が続発した 浸潤性腎孟・尿管癌 7 例中 5 例の腫瘍発育様式は PIT であった(表 5 )。また, 残り 2 例も腫瘍の一部に PIT の発育様式が認められた(表 5 ). Kakizoe らの報告の 如く, PIT 腫瘍が PNT 腫瘍から発生し得るとすれば, 今回の浸潤性腎孟・尿管癌に続発した Ta 膀胱癌は PIT 腫瘍の早期腫瘍と考えることも可能ではないだ ろうか. すなわち，自験例において浸潤性腎孟・尿管 癌に続発した Ta 膀胱癌は, 術後の膀胱鏡検查により 早期に発見されなければ浸潤癌となった可能性もある のではないか.この仮定が成り立つとすれば，先行例 及び同時例で認められた傾向が続発例においても存在 する事になる。

Habuchi らは，浸潤性腎孟・尿管癌に続発した 3 例 の膀胱癌と膀胱癌に続発した 1 例の尿管癌の $\mathrm{p} 53$ 遺伝 子解析を行い，全ての症例において両者が同一の変異 を有することから，同一のクローンから発生している 可能性を報告した ${ }^{15)}$. また，前述の如く, Lunec らは 同時例に扔いても腫瘍が単クローン性である可能性を 報告している ${ }^{10)}$.これらの報告は, 異時性もしくは同時 性に尿路上皮癌が存在する場合，その生物学的性格が 類似する可能性を示しており，今回の検討結果はこれ らの報告と矛盾しないものと思われる。

加えて, 腎孟・尿管癌と合併膀腅癌の異型度におい ても，32例中 23 例で異型度は一致していた。文献上も 両者の異型度が相関するとの報告があり ${ }^{4)}$, 深達度の みならず異型度の点からも両者の生物学的類似性が推 察される。しかし，一方では，両者の異型度には一定 の関係が認められないとする報告もある ${ }^{6)}$.また, 自験 例においても 9 例（28\%）の症例では異型度が異なっ ていることから，必ずしも全ての合併例に関して両者 の生物学的性格が類似すると考えられる訳ではない.

今回の検討は臨床症例からの推察にすぎず，尿路上 皮癌の発生機序に関し言及し得るものではない。加え て, 今回の推論の根拠となった対象症例も数的に十分 とは言えず, 事実, 前述の異型度のみならず, 深達度 に関しても一定の関係がないとする報告もある ${ }^{4)}$. 今 後は, 更に症例を加え両者の関係を確認すると同時に, 分子生物学的検索を含めた基礎的検討が両者の関係を 明確にするために必要と思われる。

以上の如く, 浸潤性腎孟・尿管癌に続発する膀胱癌 
の真の性格は, 今後の検討を要する問題と思われる. しかし，自験例において，Ta 腎盂・尿管癌に続発した 膀胱癌11例が全例 Ta であったのに対し，浸潤性腎 孟・尿管癌では10例中 3 例に浸潤性膀胱癌の合併を認 めた．合併数は少ないものの，浸潤性腎盂・尿管癌の 術後は浸潤性膀胱癌の発生に関し, 特に注意深い経過 観察が必要と思われた。

なお，本論文の要旨は第84回日本泌尿器科学会総会にて 報告した。

\section{文献}

1) Kaplan, J.H., McDonald, J.R. and Thompson, G.J.: Multicentric origin of papillary tumors of the urinary tract. J. Urol., 66, 792-604, 1951.

2) Harris, A.L., Phil, D. and Neal, D.E.: Bladder cancer-field versus clonal origin. N. Engl. J. Med., 326, 759-761, 1992.

3) Murphy, D.M., Zincke, H. and Furlow, W. L. : Primary grade 1 transitional cell carcinoma of the renal pelvis and ureter. J. Urol., 123, 629-631, 1980.

4）上条利幸，本間之夫，镪和田滋，東原英二, 阿曽佳郎：腎盂尿管腫瘍と膀腃癌の併発症例 に関する臨床的検討。日泌尿会誌，84，2003 -2007, 1993.

5）松本 尚, 大園誠一郎, 谷 善啓, 黒岡公雄, 辻本賀洋, 藤本清秀, 百瀬 均, 金子佳照, 吉田克法, 岡本新司, 佐々木憲二, 丸山良夫, 平尾佳彦, 岡島英五郎：膀胱癌の併発がみら れた腎孟・尿管腫瘍症例の検討. 泌尿紀要, 35, 239-246, 1989.

6) Rubenstein, M.A., Walz, B.J. and Bucy, J. G.: Transitional cell carcinoma of the kidney : 25-year experience. J. Urol., 119, 594-597, 1978.

7）塚本拓司，藤岡俊夫，波多野智己，中野浩之， 石川清仁, 長久保一朗：T1b 及び T2 膀胱癌 に対する TUR の適応に関する考察. 日泌尿
会誌，85，760-767， 1994.

8) Siref, L.E. and Zincke, H.: Radical cystectomy for historical and pathological T1, N0, M0 (satge A) transitional cell cancer. Urology, 31, 309-311, 1988.

9) Malkowicz, S.B., Nichols, P., Lieskovsky, G., Boyd, S.D., Huffman, J. and Skinner, D. G.: The role of radical cystectomy in the management of high grade superficial bladder cancer. J. Urol., 144, 641-645, 1990.

10) Lunec, J., Challen, C., Wright, C., Mellon, K. and Nesl, D.E. : c-erb B-2 amplification and identical p53 mutations in concomitant transitional carcinomas of renal pelvis and urinary bladder. Lancet, 339, 439-440, 1992.

11) Shinka, T., Uekado, Y., Aoshi, H., Hirano, A. and Ohkawa, T.: Occurrence of uroepithelial tumors of the upper urinary tract after the initial diagnosis of bladder cancer. J. Urol., 140, 745-748, 1988.

12) Koss, L.G.: Mapping of the urinary bladder: Its impact on the concepts of bladder cancer. Hum. Pathol., 10, 533-548, 1979.

13) Kakizoe, T., Tobis, K., Takai, K., Tanaka, Y., Kishi, K. and Teshima, S.: Relationship between papillary and nodular transitional cell carcinoma in the human urinary bladder. Cancer Res., 54, 784-788, 1994.

14) Sidransky, D. and Edward, M. : Molecular genetics and biochemical mechanisms in bladder cancer. Urol. Clin. North. Am., 19, 629-639, 1992.

15) Habuchi, T., Takahashi, R., Yamada, H., Kakehi, Y., Sugiyama, T. and Yoshida, O. : Metachronous multifocal development of urothelial cancers by intraluminal seeding. Lancet, 342, 1087-1088, 1993. （1996年5月2日受付，1997年1月27日受理） 